\title{
Ethyl acetate extract of Elephantopus mollis Kunth induces apoptosis in human gastric cancer cells
}

\author{
Tran Dang Thanh Tam ${ }^{1 \dagger}$, Truong Thi Bich Ngoc ${ }^{1,2,3 \dagger}$, Nguyen Thi Hoai Nga ${ }^{1,2,4}$, Nguyen Thi My Trinh 1,2,3, \\ Tran Linh Thuoc 1,2,3,4 and Dang Thi Phuong Thao ${ }^{1,2,3,4^{*}}$
}

\begin{abstract}
Background: Gastric cancer is one of the most leading causes of cancer death worldwide. Therefore, treatment studies have been being conducted, one of which is screening of novel agents from medicinal herbs. Elephantopus mollis Kunth (EM) belonging to Asteraceae family is a perennial herb with several therapeutic properties including anticancer activity. However, the effect of this species on gastric cancer has not been reported yet. In this study, cytotoxicity of different EM crude extracts was investigated on AGS gastric cancer cell line. Besides, the effects of extract on nuclear morphology, caspase-3 activation, and gene expression were also explored.
\end{abstract}

Results: The results showed that ethyl acetate extract exhibited a remarkably inhibitory ability $\left(I C_{50}=27.5 \mu \mathrm{g} / \mathrm{ml}\right)$ on the growth of AGS cells, while causing less toxicity to normal human fibroblasts. The extract also induced apoptotic deaths in AGS cells as evidenced by cell shrinkage, formation of apoptotic bodies, nuclear fragmentation, caspase-3 activation, and the upregulation of BAK and APAF-1 pro-apoptotic genes related to mitochondrial signaling pathway. Specifically, BAK and APAF-1 mRNA expression levels showed 2.57 and 2.71-fold increases respectively.

Conclusions: The current study not only proved the anti-gastric cancer activity of EM ethyl acetate extract but also proposed its molecular mechanism. The extract could be a potential candidate for further investigation.

Keywords: Elephantopus mollis Kunth, Ethyl acetate extract, Gastric cancer, Cytotoxicity, Apoptosis

\section{Background}

Gastric cancer is the fifth most frequently diagnosed cancer and third leading cause of cancer death worldwide, with over 1 million newly diagnosed cases and 783,000 deaths each year [1]. Although there have been efforts in Helicobacter pylori infection treatment [2, 3] and earlier diagnosis [4], the mortality incidence remains high [1]. For gastric cancer, surgery is the main curative

\footnotetext{
*Correspondence: thaodp@hcmus.edu.vn

${ }^{\dagger}$ Tran Dang Thanh Tam and Truong Thi Bich Ngoc contributed equally to this work.

${ }^{3}$ Laboratory of Cancer Research, VNU-HCM, University of Science, Duong so 4, Linh Trung, Thu Duc, Ho Chi Minh City 700000, Vietnam

Full list of author information is available at the end of the article
}

therapy, while chemotherapy or chemoradiation can be used in combination [5]. However, the relapse of tumor [6], drug resistance [7], metastasis of cancer cells [8], and side effects of chemotherapy $[9,10]$ present as challenges affecting treatment efficacy and shortening survival time of patients. For those reasons, studies on gastric cancer treatment are ongoing, among which is screening of novel anticancer agents from nature [11]. Medicinal herbs are popularly used in folk medicine with several therapeutic properties, so they are considered as potential sources for investigation.

Elephantopus mollis Kunth (EM) belonging to Asteraceae family is a perennial herb up to $40 \mathrm{~cm}$ tall. This species is native to Central and South America, but 
also appears in Africa, Eastern Asia, Australia and Pacific Islands. In traditional folk medicine, EM is used as a febrifuge, diuretic, and antidote for snakebite. The whole plant is utilized to treat diarrhea, while leaves are used for ulcers and eczema [12]. In scientific reports, EM has been proved antibacterial [13], antiinflammatory [14], and anticancer activities. The crude extracts of EM could inhibit varied human cancer cell lines, including breast carcinoma $[15,16]$, lung carcinoma [15-17], liver carcinoma [15, 16], leukemia [17], and colorectal carcinoma [15]. Regarding molecular mechanism, ethyl acetate extract could induce apoptotic deaths in HepG2 liver carcinoma cells as indicated by DNA fragmentation and caspase-3 activation [16], while methanol extract caused loss of mitochondrial integrity and exerted the increase in reactive oxygen species (ROS) level in MCF-7 breast carcinoma cells [16]. The ethyl acetate extract could also trigger apoptosis in A549 lung carcinoma cells by upregulating pro-apoptotic genes $(B A K$ and $B I D)$ and downregulating anti-apoptotic gene $B C L-2$ [17]. Some triterpenes, sesquiterpene lactones and phenolic acid compounds from this species exhibited substantial anticancer activity [18-21]. Specifically, EM23 compound, a sesquiterpene lactone, was toxic to chronic and acute leukemia cells $\left(\mathrm{IC}_{50}=10.8\right.$ and $1.9 \mu \mathrm{M}$ respectively) due to thioredoxin system inhibition leading to the increase in intracellular ROS level, the activation of ASK-1/ MAPK pathway and apoptotic deaths [21]. In addition, recently, EM2, a monomeric sesquiterpene lactone called $2 \beta$-methoxy-2- deethoxyphantomolin, was proved to inhibit liver carcinoma cells $\left(\mathrm{IC}_{50}=5.89 \mu \mathrm{M}\right)$ by causing $\mathrm{G} 2 / \mathrm{M}$ arrest, exerting endoplasmic reticulum stress, and activating JNK pathway [22]. Thus, it is obvious that although anticancer activity of EM has been studied since 1970s, its potential has not been fully exploited yet.

Although there are several studies on anticancer activity of EM, no data has been recorded on its capacity towards gastric cancer yet. Therefore, in our study, cytotoxicity of EM crude extracts was investigated on AGS human gastric adenocarcinoma cell line.

\section{Methods}

\section{Plant materials}

Elephantopus mollis Kunth (local name: "cúc chỉ thiên mềm”, English name: soft elephant's foot) was harvested in Bidoup - Nui Ba Vietnam National Park, Lam Dong Province, Vietnam. The plant was identified by Laboratory of Plants, University of Science, Vietnam National University, Ho Chi Minh City, Vietnam (voucher specimen: PHH0004880).

\section{Chemicals}

Solvents including ethanol, ethyl acetate and petroleum ether were purchased from Xilong (China). DMSO (99.9\% (v/v)) was supplied by Sigma-Aldrich (Germany). Cell culture media consisting of RPMI-1640 and high glucose DMEM were obtained from Himedia (India) and Sigma-Aldrich (Germany). Fetal bovine serum (FBS), trypsin and MTT (3-(4,5-Dimethylthiazol-2-yl)-2,5-diphenyltetrazolium bromide) were supplied by Sigma-Aldrich (Germany). Doxorubicin was supplied by Ebewe Pharma (Austria). Paraformaldehyde and Triton-X100 were obtained from Scharlau (Spain) and Pancreac AppliChem (Spain-Germany-Italia). Anti-cleaved caspase-3 antibodies (\#9661), secondary antibodies (\#A-11008), and normal goat serum (NGS) were purchased from Cell Signaling Technology (USA), Invitrogen (USA), and Vector Laboratories (Japan) respectively. TriSure Kit for RNA extraction, Tetro cDNA Synthesis Kit, and SensiFAST ${ }^{\mathrm{TM}}$ HRM Realtime PCR Kit were obtained from Bioline (UK). qPCR primers were supplied by PhuSa (Vietnam).

\section{Plant extract preparation}

Dried whole-plant materials were ground into powder. Next, the plant powder was immersed in $70 \%$ ethanol $($ ratio 1:10 $(\mathrm{w} / \mathrm{v}))$. Then, the whole solution was collected, filtered and concentrated by a rotary evaporator (Hahnvapor, Korea). After that, part of the solution was dried by a freeze drier (Benchtop K Virtis, USA) to obtain ethanol-extract powder. The remaining solution was sequentially extracted with petroleum ether and ethyl acetate solvents (ratio 1:1 (v/v)), then also concentrated by the rotary evaporator and dried by the freeze drier to gain powders of petroleum ether, ethyl acetate and water extracts. The efficiency of total extraction was $8.7 \%(\mathrm{w} / \mathrm{w})$ based on the dry weight of whole-plant materials.

The extract powders were dissolved in $99.9 \%(\mathrm{v} / \mathrm{v})$ DMSO (Merck, Germany) and stored at $-20^{\circ} \mathrm{C}$. Before experiments, the extracts were diluted in PBS solution, then filtered by sterile $0.22-\mu \mathrm{m}$ membranes.

\section{Cell line culture}

Two cell lines were used in this study, including AGS human gastric adenocarcinoma (ATCC, CRL-1739) and BJ-5ta human normal fibroblast immortalized with hTERT (ATCC, CRL-4001). AGS cell line was cultured in RPMI-1640 medium supplemented with 10\% FBS, while BJ-5ta cell line was cultured in high glucose DMEM medium supplemented with $10 \%$ FBS. The cells were cultured in an incubator (ESCO, Singapore) at $37^{\circ} \mathrm{C}$ supplied with $5 \% \mathrm{CO}_{2}$ atmosphere. The culture 
medium was renewed every 2-3 days and cells were passaged when the confluence reached $70-80 \%$.

\section{Cytotoxicity assay}

Firstly, cells were detached from culture surface by $0.25 \%$ trypsin- $0.53 \mathrm{mM}$ EDTA, then centrifuged to obtain cell pellet. The pellet was resuspended in fresh medium and cell density was identified using Neubauer chamber (Hirschmann, Germany). After that, $100 \mu \mathrm{l}$ of cell suspension $\left(10^{5}\right.$ cells $\left./ \mathrm{mL}\right)$ was transferred into each well of 96-well plate and incubated overnight. Next, the medium was replaced with fresh medium containing extracts at experimental concentrations. In initial screening step, the extract concentration of $40 \mu \mathrm{g} / \mathrm{ml}$ was used, while in $\mathrm{IC}_{50}$ identification step, the concentrations ranged from 0.8 to $100 \mu \mathrm{g} / \mathrm{ml}$. The final concentration of DMSO in each well was kept less than $0.1 \%(\mathrm{v} / \mathrm{v})$. Control untreated cells were treated with $0.1 \%(\mathrm{v} / \mathrm{v})$ DMSO. Blank wells containing medium and extract (or 0.1\% DMSO) were also established. The plate was incubated at $37^{\circ} \mathrm{C}$ for $48 \mathrm{~h}$, then $5 \mu \mathrm{l}$ of $5 \mathrm{mg} / \mathrm{ml} \mathrm{MTT}$ was transferred into wells. After 4-h incubation, $60 \mu \mathrm{l}$ of lysis buffer (30\% (w/v) SDS, $0.03 \mathrm{~N}$ $\mathrm{HCl})$ and $90 \mu \mathrm{l}$ of DMSO $(99.9 \%(\mathrm{v} / \mathrm{v}))$ were added. The absorbances were measured at wavelength of $550 \mathrm{~nm}$. The percentage growth inhibition was calculated following the formula:

$$
\mathrm{I} \%=100 \%-\left(\mathrm{OD}_{\text {treated }}-\mathrm{OD}_{\text {blank }}\right) /\left(\mathrm{OD}_{\text {control }}-\mathrm{OD}_{\text {blank }}\right) \times 100 \%
$$

The whole assay was independently repeated in triplicate. $\mathrm{IC}_{50}$ (concentration of $50 \%$ growth inhibition) values were interpolated by GraphPad Prism 6. Meanwhile, selectivity index (SI) value was calculated by the ratio of $\mathrm{IC}_{50}$ of extract on normal cell line to $\mathrm{IC}_{50}$ of extract on cancer cell line.

\section{Analysis of cell growth}

Cells were seeded into wells at density of $10^{5}$ cells $/ \mathrm{mL}$ and treated with extract at $\mathrm{IC}_{50}$ concentration. The cell growth of treated and untreated samples was indirectly quantified through OD values of MTT assay at different time points of $0 \mathrm{~h}, 24 \mathrm{~h}, 48 \mathrm{~h}$, and $72 \mathrm{~h}$.

\section{Analysis of cell morphology}

Cells were seeded into wells at density of $10^{5}$ cells $/ \mathrm{mL}$ and treated with extract at $\mathrm{IC}_{50}$ concentration. Cell morphologies of treated and untreated samples were captured by inverted microscope Nikon Eclipse TiU (Nikon, Japan) after $48 \mathrm{~h}$ treatment.

\section{DAPI staining and immunofluorescence staining} with anti-cleaved caspase 3 antibodies

After being seeded into wells at density of $10^{5}$ cells $/ \mathrm{mL}$, cells were treated with extract at $\mathrm{IC}_{50}$ concentration. After 48 -h incubation, cells were fixed in $4 \%(\mathrm{v} / \mathrm{v})$ paraformaldehyde for 10 mins, permeabilized with $0.1 \%(\mathrm{v} / \mathrm{v})$ Triton-X100 for 5 mins.

For DAPI-dye staining, cells were incubated with DAPI solution $(1: 250(\mathrm{v} / \mathrm{v}))$ for 15 mins, then washed thrice with PBS solution before being visualized under a fluorescence microscope (Nikon, Japan).

For immunofluorescence staining, after the permeabilization, experimental wells were blocked by $10 \%(\mathrm{v} / \mathrm{v})$ NGS for 30 mins. Subsequently, cells were incubated with anti-cleaved caspase-3 antibodies $(1: 200(\mathrm{v} / \mathrm{v}))$ for $1 \mathrm{~h}$, washed thrice with PBS solution before being simultaneously incubated with secondary antibodies (1:500 $(\mathrm{v} / \mathrm{v}))$ and DAPI solution $(1: 250(\mathrm{v} / \mathrm{v}))$ for $1 \mathrm{~h}$. Finally, the cells were washed with PBS solution and observed under the fluorescence microscope.

\section{Quantitative RT-PCR}

Cells were seeded into wells at density of $10^{5}$ cells $/ \mathrm{mL}$ and treated with extract at $\mathrm{IC}_{50}$ concentration. After 48 -h incubation, total RNA was extracted using TriSure Kit following manufacturer's instructions. Next, $500 \mathrm{ng}$ of total RNA was converted into cDNA using Tetro cDNA synthesis Kit and oligo-dT primers. Finally, qPCR was conducted by Lightcycler 96 System (Roche Diagnostics, Germany) using SensiFAST HRM Kit and $1 \mu \mathrm{l}$ of cDNA template. Thermal cycling conditions were as follows: 1 cycle denaturation of $95^{\circ} \mathrm{C}$ for 2 mins, 45 cycles of $95^{\circ} \mathrm{C}$ for $5 \mathrm{~s}$, annealing temperature for $10 \mathrm{~s}, 72^{\circ} \mathrm{C}$ for $10 \mathrm{~s}$. The whole assay was independently repeated in triplicate.

Relative mRNA expression levels of treated samples compared to control samples were calculated by the formula $2^{-\Delta \Delta \mathrm{Ct}}$. In the current study, genes including $B A X$, $B A K, B I D, A P A F-1, B C L-2$, TP53 were investigated, accompanied by reference gene $A C T B$ ( $\beta$-actin). Primer sequences were referred to previous documents [23-27]. Primer sequences were as followed: $B A X-F$ : CAAACT GGTGCTCAAGGCCC, BAX-R: GGGCGTCCCAAA GTAGGAGA, BAK-F: TTTTCCGCAGCTACGTTT TT, $B A K-R$ : TGGTGGCAATCTTGGTGAAGT, $B I D-F$ : TGGACTGTGAGGTCAACAACG, BID-R: AGTCTG CAGCTCATCGTAGCC, APAF1-F: CACGTTCAAAGG TGGCTGAT, APAF1-R: TGGTCAACTGCAAGGACC AT, BCL2-F: CTGGTGGACAACATCGCCCT, BCL2-R: TCTTCAGAGACAGCCAGGAGAAAT, TP53-F: GCC CAACAACACCAGCTCCT, TP53-R: CCTGGGCAT CCTTGAGTTCC, ACTB-F: TCCTGTGGCATCCAC GAACT, ACTB-R: GAAGCATTTGCGGTGGACGAT. 


\section{Statistical analysis}

In this study, experimental data were analyzed by GraphPad Prism 6 software. The results were described as mean \pm SD of at least three independent experiments. The non-linear regression curves describing the relationship between logarithm of extract concentrations and I\% were established by using GraphPad Prism, from which $\mathrm{IC}_{50}$ values were interpolated by the software. The differences of mean were tested by unpaired Student's t-test (two-tailed). The $p$-value less than 0.05 indicates a statistically significant difference between two groups.

\section{Results}

\section{Cytotoxicity of EM extracts on AGS cell line}

To investigate the cytotoxicity of EM extracts, the extract concentration of $40 \mu \mathrm{g} / \mathrm{ml}$ was utilized. The results showed that EM-EA and EM-PE extracts exhibited remarkable inhibition ( $\mathrm{I} \%=66.7$ and $55.8 \%$ respectively) (Fig. 1a). Therefore, EM-EA and EM-PE extracts were subjected to $\mathrm{IC}_{50}$ analysis with concentrations ranging from 0.8 to $100 \mu \mathrm{g} / \mathrm{ml}$.

At the highest concentration $(100 \mu \mathrm{g} / \mathrm{ml})$, EM-EA and EM-PE extract caused 67 and $90 \%$ inhibition on AGS cells; meanwhile, for the concentrations less than $10 \mu \mathrm{g} /$ $\mathrm{ml}$, the extracts exhibited no cytotoxicity (Fig. 1b). The $\mathrm{IC}_{50}$ values of EM-EA and EM-PE extracts towards AGS cell line were 27.5 and $37.2 \mu \mathrm{g} / \mathrm{ml}$, respectively (Table 1 ). Following the criterion of National Cancer Institute
Table 1 The $\mathrm{IC}_{50}$ and the selectivity index values of Elephantopus mollis Kunth extracts on AGS cell line

\begin{tabular}{|c|c|c|c|c|c|}
\hline & \multicolumn{3}{|c|}{$I C_{50}(\mu \mathrm{g} / \mathrm{mL})$} & \multicolumn{2}{|c|}{$\begin{array}{l}\text { Selectivity index } \\
\text { (SI) }\end{array}$} \\
\hline & EM-EA & EM-PE & DOX & EM-EA & EM-PE \\
\hline AGS & $27.5 \pm 10.9$ & $37.2 \pm 8.7$ & $0.26 \pm 0.02$ & 2.6 & 1.0 \\
\hline BJ-5ta & $72.2 \pm 12.6$ & $38.5 \pm 5.1$ & $1.63 \pm 0.63$ & & \\
\hline
\end{tabular}

The assay was repeated at least three times independently. The SI value of extract was calculated by the ratio of $\mathrm{IC}_{50}$ on normal fibroblast cell line (BJ-5ta) to $\mathrm{IC}_{50}$ on cancer cell line (AGS). Abbreviations: DOX doxorubicin

(NCI), a crude extract with $\mathrm{IC}_{50}$ value less than $20-30 \mu \mathrm{g} /$ $\mathrm{ml}$ is considered as having highly cytotoxic effect $[16,28]$. Interestingly, EM-EA extract was less toxic to BJ-5ta normal fibroblast cell line $\left(\mathrm{IC}_{50}=72.2 \mu \mathrm{g} / \mathrm{ml}\right)$. The selectivity index (SI) value of extract was used to emphasize the selective effect on cancer cell line compared to normal cell line [29], in which $\mathrm{SI} \geq 2$ indicates selective toxicity towards cancer cells. The SI values of EM-EA and EM-PE extracts were 2.6 and 1.0 (Table 1). Therefore, EM-EA extract was subjected to further analysis.

\section{Effect of EM-EA extract on cell growth}

The AGS cell growth of EM-EA-treated samples was indirectly evaluated through $\mathrm{OD}_{550 \mathrm{~nm}}$ values of MTT assay.

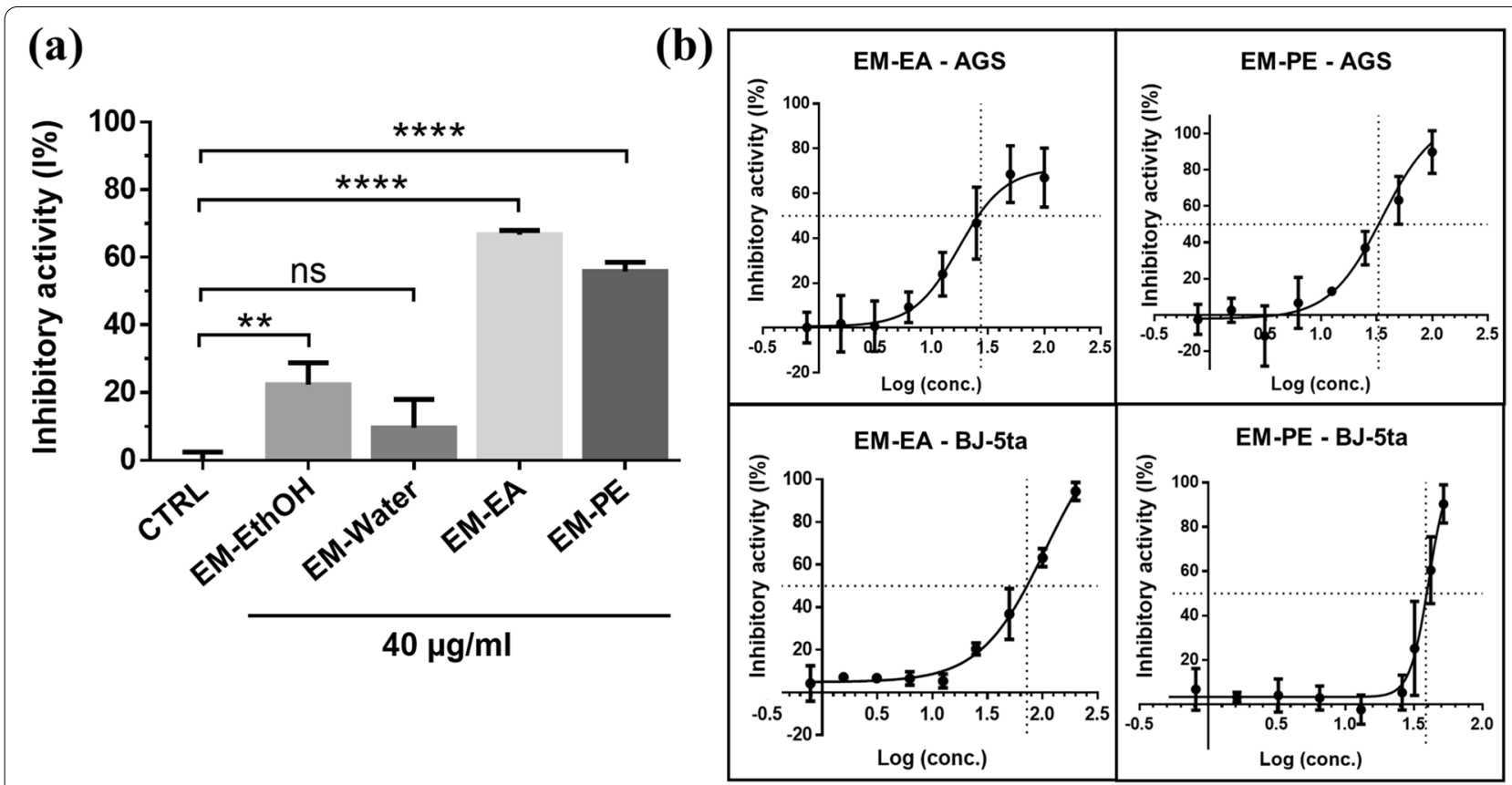

Fig. 1 The cytotoxicity of EM extracts. a The percentage growth inhibition of EM extracts at concentration of $40 \mu \mathrm{g} / \mathrm{ml}$ on AGS cell line. $\mathbf{b}$ The percentage growth inhibition of EM-EA and EM-PE extracts at experimental concentrations on AGS and BJ-5ta cell lines. Each value represents mean \pm SD of at least three independent experiments. The statistical differences were analyzed by two-tailed unpaired Student's t-tests $\left({ }^{* *} p<0.01\right.$; $\left.{ }^{* * * *} p<0.0001 ; n s, p>0.05\right)$ 
In this assay, AGS samples were treated with EM-EA extract at $\mathrm{IC}_{50}$ concentration, then $\mathrm{OD}_{550 \mathrm{~nm}}$ values were measured at time points of $0,24,48$, and $72 \mathrm{~h}$.

The $\mathrm{OD}_{550 \mathrm{~nm}}$ values of EM-EA-treated samples decreased by $18.5 \%$ at $24 \mathrm{~h}(p=0.0394)$ when compared with that at $0 \mathrm{~h}$ and remained unchanged from $24 \mathrm{~h}$ to $72 \mathrm{~h}$ (Fig. 2a). The $\mathrm{OD}_{550 \mathrm{~nm}}$ values of untreated samples continuously increased. Particularly, the values at $24 \mathrm{~h}$, $48 \mathrm{~h}$, and $72 \mathrm{~h}$ increased $1.5,1.3$, and 1.4 times respectively $(p=0.0018,0.0106$, and 0.0001$)$. The inhibitory percentages at 24,48 , and $72 \mathrm{~h}$ were $45.1,53.2$, and $77.3 \%$ (Fig. 2b). These results suggested that with EM-EA treatment, AGS cells might experience cell deaths or growth inhibition. To elucidate, cell morphology of EM-EAtreated samples was analyzed next.

\section{Effect of EM-EA extract on cell morphology}

The changes of cell morphology were observed under an inverted microscope. As illustrated in Fig. 3b, for control samples, cells spread on culture surface with characteristic morphology. Meanwhile, at $\mathrm{IC}_{50}$ concentration of EM-EA extract, treated cells turned round, shrunk and be surrounded by several small bodies (Fig. 3c). These features are similar to cell morphology of apoptotic death depicted previously [30]. The percentage of cells owning abnormal morphology of EM-EA-treated samples was $28.4 \%$, which is 5.5 times as high as that of untreated samples (5.2\%) ( $p=0.0215)$ (Fig. 3e).

Besides, in this study, doxorubicin, a chemotherapeutic agent and apoptosis inducer [31], was also used for comparison. The results showed that EM-EA-treated samples got the same morphological features as doxorubicintreated ones (Fig. 3d). For that reason, it is suggested that cells treated with EM-EA extract might experience apoptotic deaths.

\section{Nuclear fragmentation with EM-EA treatment}

It is well-known that apoptotic cells have nuclear fragmentation [32]. Thus, to examine, EM-EA-treated samples were stained with DAPI DNA-binding dye, then visualized under fluorescence microscope.

As shown in Fig. 4b, the nuclei of EM-EA-treated samples had specific phenomena such as shrinkage, condensation, and fragmentation at locations of abnormal cells; meanwhile, for control samples, cell nuclei were fairly identical in shape and size (Fig. 4a). Besides, the nuclear shrinkage and condensation were also observed in doxorubicin-treated samples (Fig. 4c). The percentage of abnormal nuclei of EM-EA-treated samples was $20.9 \%$, which is greater than that of untreated ones $(1.1 \%)(p<0.0001)$ (Fig. $4 \mathrm{~d})$. These results strongly support that EM-EA extract activated apoptotic deaths in AGS cells.

\section{Caspase-3 activation induced by EM-EA extract}

Caspase-3, a cysteine-aspartic acid protease, is an executive enzyme which can trigger apoptotic cell death by activating other enzymes to disrupt nuclear structure, cause cell shrinkage and induce membrane blebbing. The activation of caspase-3 is considered as marker of apoptosis [33]. In our study, activated-caspase- 3 signals appeared at same places with fragmented nuclei of both EM-EA-treated and
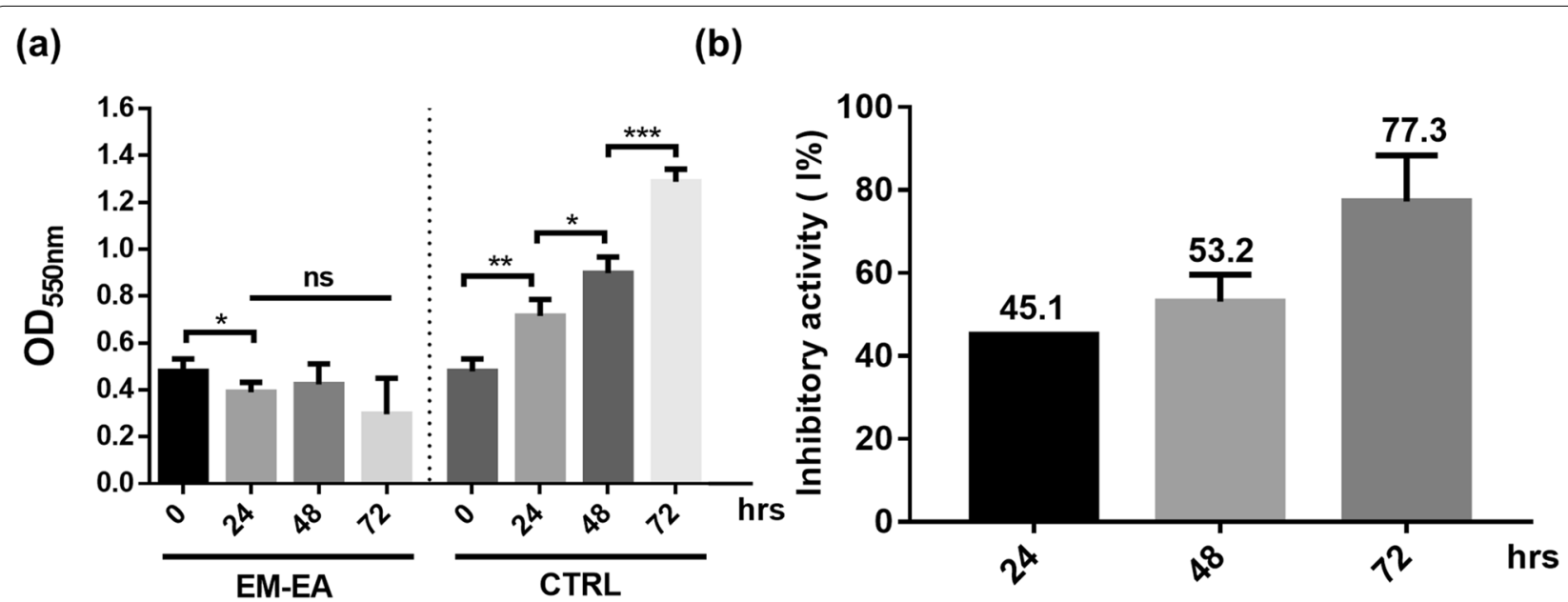

Fig. 2 The effects of EM-EA extract on cell growth and percentage growth inhibition of AGS cells during time. a The OD $550 \mathrm{~nm}$ values of samples treated with EM-EA extract $(27.5 \mu \mathrm{g} / \mathrm{ml})$ and $0.1 \%(\mathrm{v} / \mathrm{v})$ DMSO (control) at different time points. $\mathbf{b}$ The percentage growth inhibition of EM-EA-treated samples when compared with control samples at different time points. Each value represents mean $\pm S D$ of four independent experiments. The statistical differences were analyzed by two-tailed unpaired Student's t-tests $\left({ }^{*} p<0.05 ;{ }^{* *} p<0.01 ; *^{* *} p<0.001 ; n s, p>0.05\right)$ 
(1)

(a)

(b)
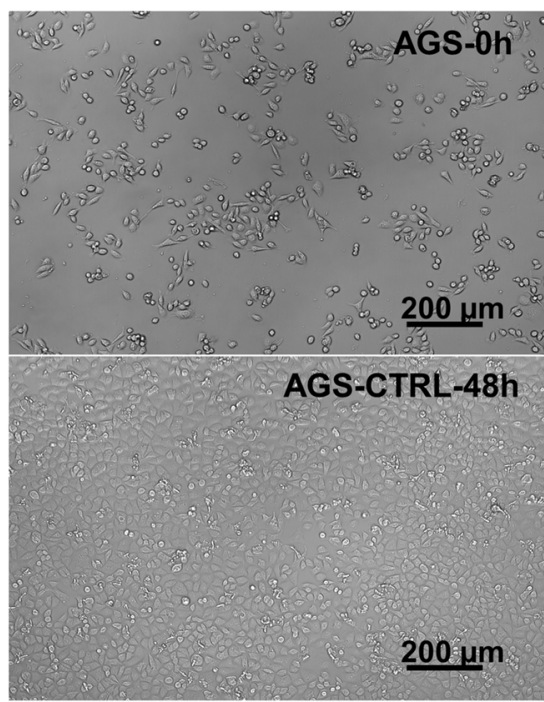

(c)

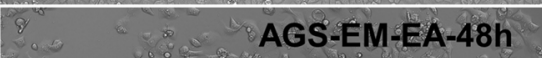

(d)
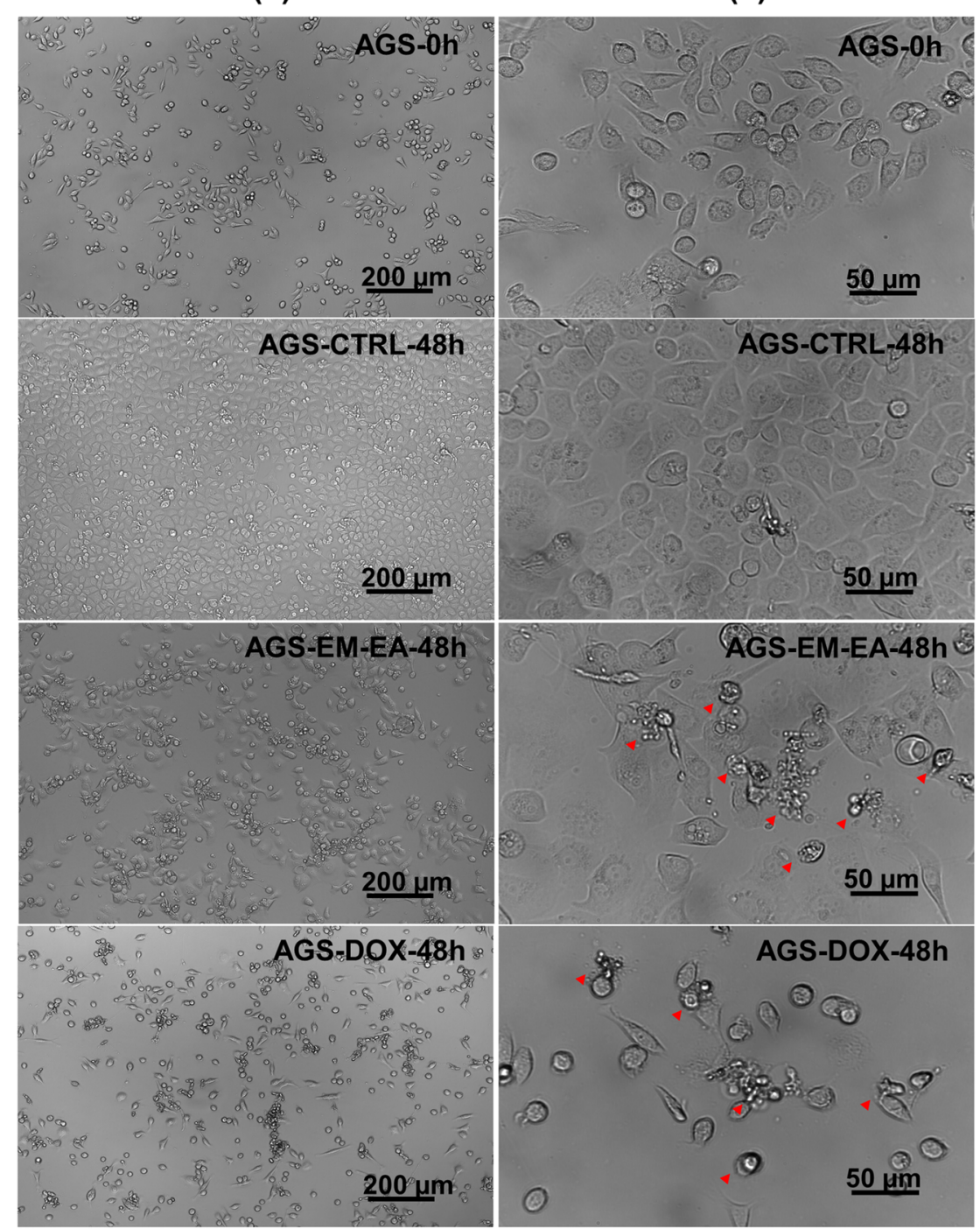

(2)



(e)

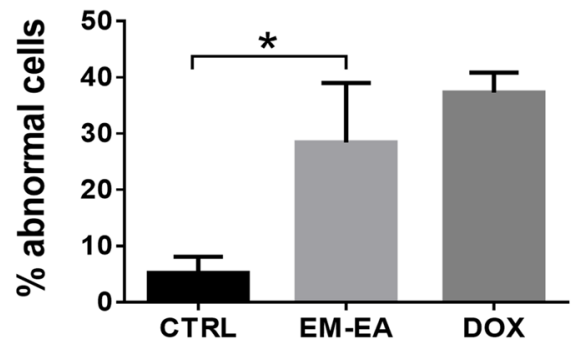

Fig. 3 The effect of EM-EA extract on cell morphology of AGS cells. a Sample at $0 \mathrm{~h}$ before treatment. $\mathbf{b}$ Control sample treated with $0.1 \%$ ( $\mathrm{v} / \mathrm{v}$ ) DMSO at 48 h. c Sample treated with EM-EA extract $(27.5 \mu \mathrm{g} / \mathrm{ml})$ at $48 \mathrm{~h}$. d Sample treated with doxorubicin $(0.3 \mu \mathrm{g} / \mathrm{ml})$ at $48 \mathrm{~h}$. e The percentage of abnormal cells in cell population of control samples $(n=3)$, EM-EA-treated samples $(n=3)$, and DOX-treated samples $(n=3)$ at $48 \mathrm{~h}$. Each value represents mean $\pm S D$. The statistical difference was analyzed by two-tailed unpaired Student's t-tests $\left({ }^{*} p<0.05\right)$. (1) Images captured at 100x magnification. (2) Images captured at 400x magnification. Arrowheads point cells with abberant morphological features 


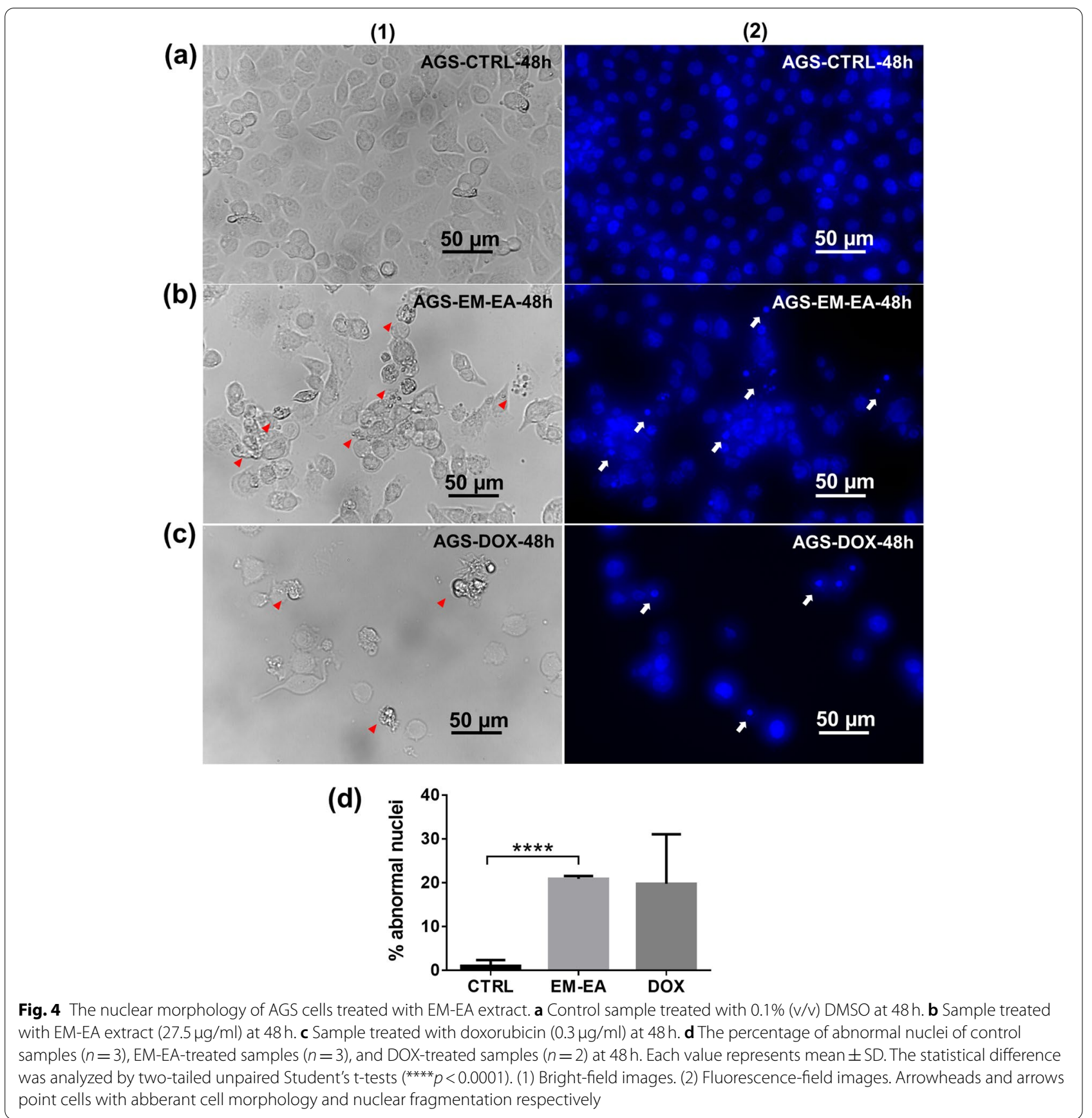

doxorubicin-treated samples (Fig. 5b, c). In comparison with control untreated cells, no signal of caspase-3 activation was observed (Fig. 5a). The percentage of activated-caspase-3-expressing cells of EM-EAtreated samples was $7.3 \%$, while that of untreated samples was $0.2 \%$ (Fig. $5 \mathrm{~d}$ ). Thus, the results demonstrate that EM-EA extract triggered apoptosis in AGS cells through caspase- 3 activation.

\section{The mechanism of apoptosis activation by EM-EA extract} in AGS gastric cancel cells

Apoptosis can be triggered by intrinsic signaling pathway through mitochondria and/or extrinsic pathway through membrane receptors [34]. In this study, to elucidate the mechanism of apoptotic activation, the expression of pro-apoptotic (BAX, BAK, BID, $A P A F-1)$ and anti-apoptotic genes $(B C L-2)$ was investigated by qRT-PCR. 


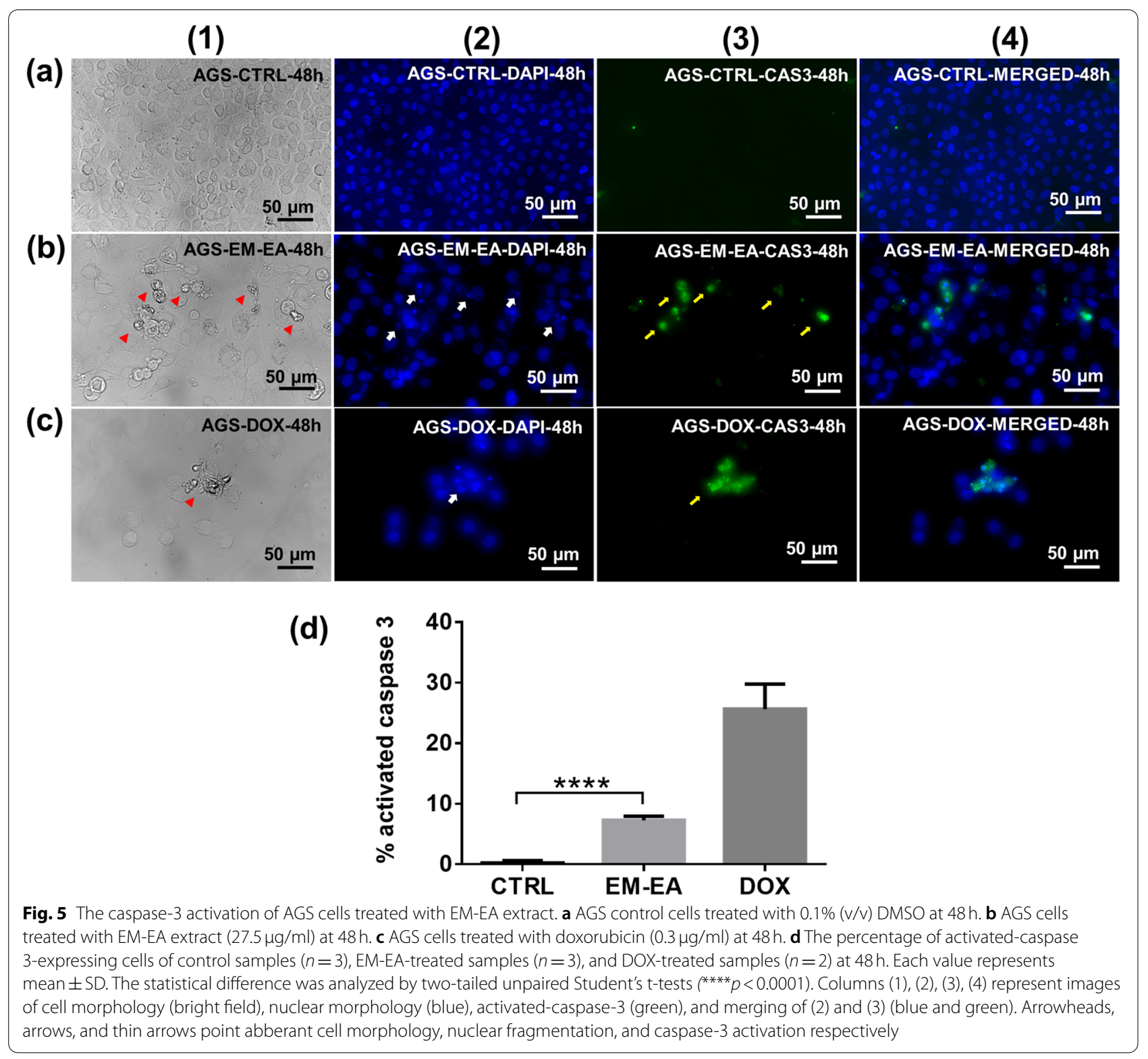

As depicted in Fig. 6a, b, the expression levels of $B I D$ and $B A X$ showed no difference between treated and untreated cells. Notably, $B A K$ and $A P A F-1$ expression levels of treated samples increased 2.57 and 2.71 times $(p=0.0029$ and 0.009 respectively) when compared with those of untreated ones (Fig. 6c, d). Surprisingly, the mRNA level of $B C L-2$ anti-apoptotic gene was also upregulated 2.05 times ( $p=0.0162$ ) (Fig. 6e), suggesting that the treated cells had response against extract impact. In addition, we also examined the expression of TP53 gene, encoding a transcriptional factor which can take part in apoptosis through regulating pro-apoptotic genes such as $B A X, B A K, A P A F-1[27,35,36]$. However, as shown in Fig. 6f, there was no difference in TP53 expression levels between treated and untreated samples.

In brief, EM-EA extract might trigger apoptosis through the upregulation of $B A K$ and $A P A F-1$ levels in AGS cells.

\section{Discussion}

Although anticancer activity of EM has been studied on liver carcinoma, lung carcinoma, leukemia cell lines, etc., no report on EM activity against gastric cancer has been published so far. Here, the cytotoxic effect of EM-EA extract on AGS gastric cancer cell line was firstly verified with $\mathrm{IC}_{50}$ of $27.5 \mu \mathrm{g} / \mathrm{ml}$, which meets the criterion of 


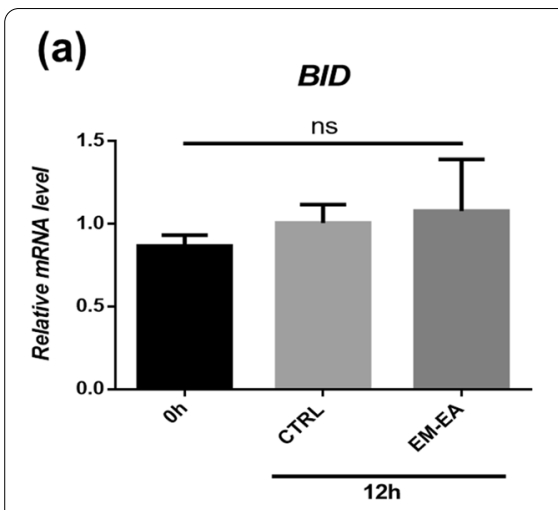

(d)

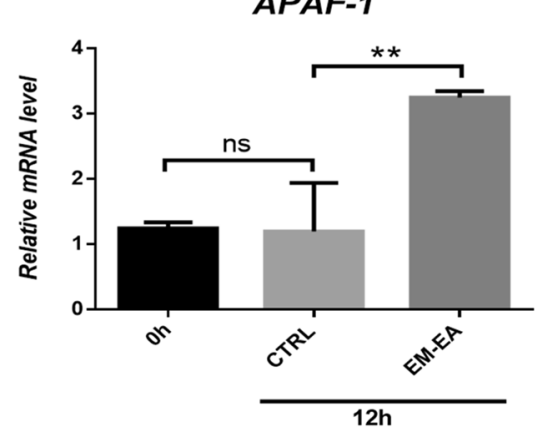

(b)

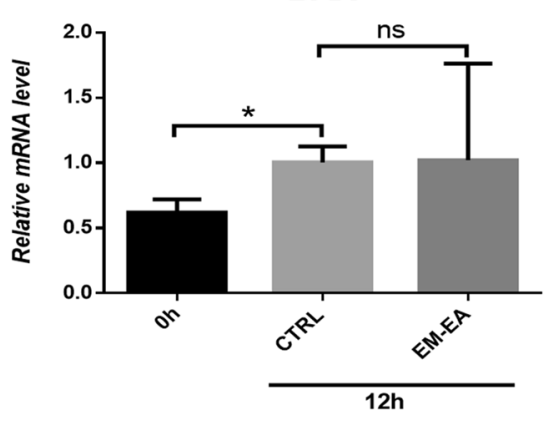

(e)

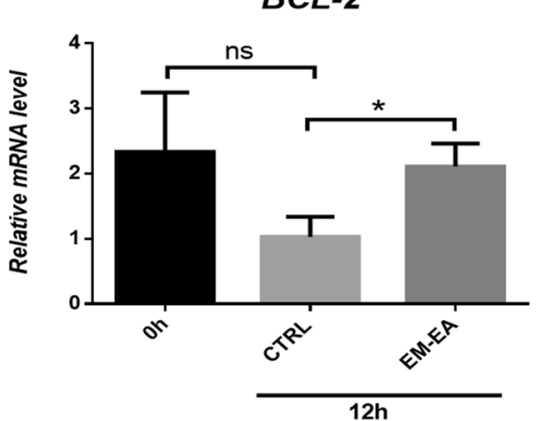

(c)

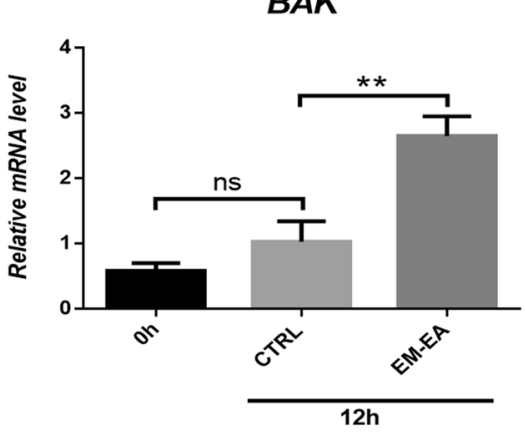

(f)

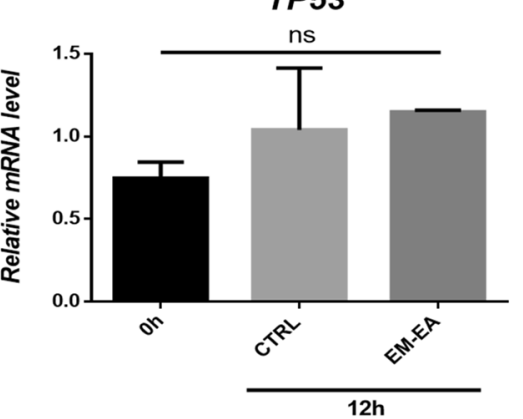

Fig. 6 The mRNA levels of apoptosis-related genes of AGS cells treated with EM-EA extract (27.5 $\mu \mathrm{g} / \mathrm{ml})$. a-f The mRNA levels of BID, BAX, BAK, APAF-1, BCL-2, TP53 genes at $12 \mathrm{~h}$. Each value represents mean $\pm \mathrm{SD}$ of three independent experiments. The statistical differences were analyzed by two-tailed unpaired Student's t-tests $\left({ }^{*} p<0.05\right.$; ${ }^{* *} p<0.01 ; \mathrm{ns}, p>0.05$ )

highly cytotoxic crude extract $\left(\mathrm{IC}_{50}<20-30 \mu \mathrm{g} / \mathrm{ml}\right)[16$, 28]. Importantly, EM-EA extract was less toxic to BJ5 ta, a normal human fibroblast cell line $\left(\mathrm{IC}_{50}=72.2 \mu \mathrm{g} /\right.$ $\mathrm{ml})$. For chemotherapeutic treatments, beside the efficacy, side effects on normal tissues are also problems to be considered. Thus, an agent causing both selective and high toxicity on cancer cells compared with normal cells would be an ideal candidate for drug development [37]. In the current study, EM-EA extract might be a potential target for further investigation.

Following the extract effects on cell growth, cell morphology, and nuclear morphology helped to evaluate the anticancer mechanism of EM-EA extract on AGS cells. The EM-EA-treated cells experienced apoptotic deaths as evidenced by characteristic features such as cell shrinkage accompanied by small disintegrated bodies, nuclear fragmentation, and caspase- 3 activation. According to previous reports, EM-EA extract could trigger apoptosis towards HepG2 liver carcinoma, A549 lung carcinoma, and HL60 leukemia cells $[16,17]$. Therefore, our results add that EM-EA extract could also induce apoptosis in AGS gastric cancer cells.

Apoptotic death could be triggered by extrinsic signaling pathway through receptors on cell membrane and/or intrinsic pathway through mitochondria [34]. For extrinsic pathway, once death-inducing ligands such as FasL/ TNFa/TRAIL bind to receptors on outer cell membrane, caspase $8 / 10$ is processed, then activate caspase 3 to initiate apoptosis. For intrinsic pathway, the oligomerization of BAX, BAK proteins would be triggered to form pores on mitochondrial outer membrane leading to the release of cytochrome $\mathrm{c}$ which then interacts with APAF-1 to form apoptosome for caspase- 3 activation. In addition, extrinsic pathway could be connected to intrinsic pathway due to the fact that activated-caspase- 8 is able to cleave BID proteins causing BAX/BAK oligomerization. On the contrary, BCL-2, anti-apoptotic protein, binds to $\mathrm{BAX} / \mathrm{BAK}$ to prevent the oligomerization in order to protect the integrity of mitochondrial membrane [38, 39]. In this study, with EM-EA treatment, expression levels of BAK and APAF-1 increased 2.57 and 2.71 times, while BAX and BID levels remained unchanged. It has been reported that gastric tumor has reduced-BAK levels when compared with normal mucosa, and the BAK overexpression could induce apoptosis in gastric cancer cells [40]. In addition, the increase in BAK expression indicates good chemotherapeutic response in advanced gastric cancer [41]. Therefore, our results, which recorded the 


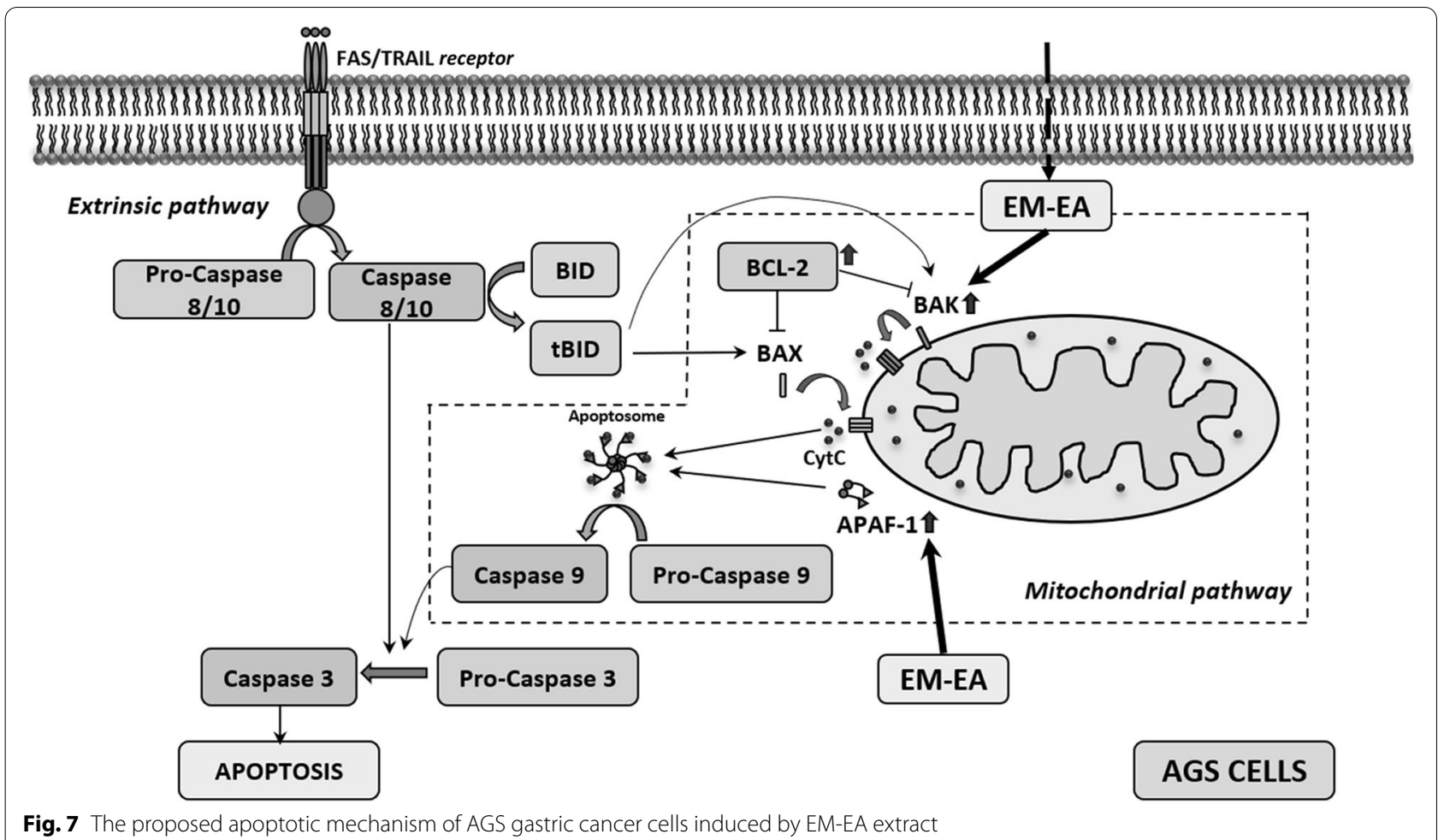

upregulation of $B A K$ mRNA level after EM-EA-extract treatment, show an optimistic sign for drug screening to treat gastric cancer. Besides, the simultaneous upregulation of $B A K$ and $A P A F-1$ levels also suggests that EM-EA extract might trigger apoptosis through mitochondrial pathway (Fig. 7). The mRNA expression of P53, a transcriptional factor which could regulate $B A K$ and $A P A F-1$ gene expression, was not different between treated and untreated samples. In this case, $B A K$ and $A P A F-1$ genes might be transcriptionally regulated by another factor, or P53 proteins might be regulated by post-translational modifications leading to their stable presence in cells [42] then prompting transcriptional activation of $B A K$ and $A P A F-1$ genes. Thus, next studies should be conducted to investigate further.

Our results also showed that with EM-EA treatment, the anti-apoptotic gene $B C L-2$ was upregulated 2.05folds. As described above, the cell densities of treated samples decreased at $24 \mathrm{~h}$ then remained unchanged from $24 \mathrm{~h}$ to $72 \mathrm{~h}$ (Fig. $2 \mathrm{a}$ ). Therefore, it might be that beside the population suffering apoptosis, some cells had resistant response towards the extract impact. There has also been a report on the correlation between increased BCL-2 level and the resistance of chemotherapeutic drugs such as 5-fluorouracil, adriamycin, mitomycin $\mathrm{C}$ in gastric cancer [43]. Importantly, despite that resistance, EM-EA extract caused a remarkable inhibition
$(\mathrm{I} \%=77.3 \%$ at $72 \mathrm{~h})$ and induced apoptosis in AGS cells due to the upregulation of $B A K$ and $A P A F-1$ expression levels.

\section{Conclusion}

Gastric cancer is one of the most common cancers with leading mortality rate. Screening of novel agents from natural sources, including medicinal herbs, is an approach in treatment research. In this study, ethyl acetate extract of Elephantopus mollis Kunth species was proved to be a potential candidate against gastric cancer. Specifically, EM-EA extract exhibited high cytotoxicity $\left(\mathrm{IC}_{50}=27.5 \mu \mathrm{g} / \mathrm{ml}\right)$ and could induce apoptosis towards AGS gastric cancer cell line. The initial investigation of mechanism pointed that apoptosis activation might be triggered through mitochondrial pathway due to the upregulation of pro-apoptotic genes such as $B A K$ and APAF-1.

\section{Abbreviations}

CAS3: Activated caspase-3; CTRL: Control; DOX: Doxorubicin; EM: Elephantopus mollis Kunth; EM-EA: Ethyl acetate extract of Elephantopus mollis Kunth; EM-EtOH: Ethanol extract of Elephantopus mollis Kunth; EM-PE: Petroleum ether extract of Elephantopus mollis Kunth; EM-Water: Aqueous extract of Elephantopus mollis Kunth; $1 \%$ : The percentage growth inhibition; $I_{50}: 50 \%$ inhibitory concentration; $\mathrm{OD}_{550 \mathrm{~nm}}$ : Optical density at wavelength $550 \mathrm{~nm}$; SI: Selectivity index. 


\section{Acknowledgements}

We thank to all members of Gene Technology and Application group for great supports in this study.

\section{Authors' contributions}

TDTT carried out the investigation, formal analysis, and visualization; TTBN conducted the investigation, formal analysis, visualization, and wrote the draft; NTHN supervised the experiments; NTMT supervised the experiments; TLT supervised the experiments; DTPT designed the study, supervised the experiments, and reviewed the draft. All authors read and approved the final manuscript.

\section{Funding}

This research is funded by Grants-in-Aid from the JSPS Core-to-Core program, B. Asia-Africa Science Platforms; and sample collection was supported by the BiDoup - Nui Ba National Park, Vietnam.

\section{Availability of data and materials}

The datasets used and/or analysed during the current study are available from the corresponding author on reasonable request.

\section{Declarations}

\section{Ethics approval and consent to participate}

Not applicable.

\section{Consent for publication}

Not applicable.

\section{Competing interests}

The authors declare that they have no competing interests.

\section{Author details}

${ }^{1}$ Department of Molecular and Environmental Biotechnology, Faculty of Biology and Biotechnology, VNU-HCM, University of Science, 227 Nguyen Van Cu, Ho Chi Minh City 700000, Vietnam. ${ }^{2}$ Laboratory of Molecular Biotechnology, VNU-HCM, University of Science, 227 Nguyen Van Cu, Ho Chi Minh City 700000, Vietnam. ${ }^{3}$ Laboratory of Cancer Research, VNU-HCM, University of Science, Duong so 4, Linh Trung, Thu Duc, Ho Chi Minh City 700000, Vietnam. ${ }^{4}$ Vietnam National University, Ho Chi Minh City, Vo Truong Toan, Linh Trung, Thu Duc, Ho Chi Minh City 700000, Vietnam.

Received: 22 June 2021 Accepted: 15 October 2021

Published online: 30 October 2021

\section{References}

1. Rawla P, Barsouk A. Epidemiology of gastric cancer: global trends, risk factors and prevention. Prz Gastroenterol. 2019;14(1):26.

2. Choi IJ, Kook M-C, Kim Y-I, Cho S-J, Lee JY, Kim CG, et al. Helicobacte pylori therapy for the prevention of metachronous gastric cancer. N Engl J Med. 2018:378(12):1085-95.

3. Ford AC, Forman D, Hunt RH, Yuan Y, Moayyedi P. Helicobacter pylori eradication therapy to prevent gastric cancer in healthy asymptomatic infected individuals: systematic review and meta-analysis of randomised controlled trials. Bmj. 2014:348.

4. Pasechnikov V, Chukov S, Fedorov E, Kikuste I, Leja M. Gastric cancer: prevention, screening and early diagnosis. World J Gastroenterol. 2014;20(38):13842.

5. Orditura M, Galizia G, Sforza V, Gambardella V, Fabozzi A, Laterza MM, et al. Treatment of gastric cancer. World J Gastroenterol. 2014;20(7):1635.

6. Deng J, Liang H, Wang D, Sun D, Pan Y, Liu Y. Investigation of the recurrence patterns of gastric cancer following a curative resection. Surg Today. 2011;41(2):210-5

7. Zhang D, Fan D. New insights into the mechanisms of gastric cancer multidrug resistance and future perspectives. Future Oncol. 2010;6(4):527-37.

8. Power DG, Kelsen DP, Shah MA. Advanced gastric cancer-slow but steady progress. Cancer Treat Rev. 2010;36(5):384-92.
9. Oun R, Moussa YE, Wheate NJ. The side effects of platinum-based chemotherapy drugs: a review for chemists. Dalton Trans. 2018;47(19):6645-53.

10. Baker J, Ajani J, Scotté F, Winther D, Martin M, Aapro MS, et al. Docetaxel-related side effects and their management. Eur J Oncol Nurs. 2009:13(1):49-59.

11. Da Rocha AB, Lopes RM, Schwartsmann G. Natural products in anticancer therapy. Curr Opin Pharmacol. 2001:1(4):364-9.

12. Kabiru A, Por LY. Elephantopus species: traditional uses, pharmacological actions and chemical composition. Adv Life Sci Technol. 2013;15:6-13.

13. Nhut PM, Thao DTP. Antibacterial activity of water extract from some folk medicine at Bidoup-Nuiba National Park, Lam dong, Vietnam. SSR Inst Int J Life Sci. 2020;6(1):2449-54.

14. Wu Z-N, Zhang Y-B, Chen N-H, Li M-J, Li M-M, Tang W, et al. Sesquiterpene lactones from Elephantopus mollis and their anti-inflammatory activities. Phytochemistry. 2017;137:81-6.

15. Kuete V, Fokou FW, Karaosmanoğlu O, Beng VP, Sivas H. Cytotoxicity of the methanol extracts of Elephantopus mollis, Kalanchoe crenata and 4 other Cameroonian medicinal plants towards human carcinoma cells. BMC Complement Altern Med. 2017;17(1):280.

16. Ooi KL, Tengku Muhammad TS, Lam LY, Sulaiman SF. Cytotoxic and apoptotic effects of ethyl acetate extract of Elephantopus mollis Kunth. In human liver carcinoma HepG2 cells through caspase-3 activation. Integr Cancer Ther. 2014;13(3):NP1-9.

17. Ngoc TTB, Nga NTH, Trinh NTM, Thuoc TL, Thao DTP. Elephantopus mollis Kunth extracts induce antiproliferation and apoptosis in human lung cancer and myeloid leukemia cells. J Ethnopharmacol. 2020;263:113222.

18. Lee K-H, Ibuka T, Huang H-C, Harris DL. Antitumor agents XIV: Molephantinin, a new potent antitumor sesquiterpene lactone from Elephantopus mollis. J Pharm Sci. 1975;64(6):1077-8.

19. Tabopda TK, Liu J, Ngadjui BT, Luu B. Cytotoxic triterpene and sesquiterpene lactones from Elephantopus mollis and induction of apoptosis in neuroblastoma cells. Planta Med. 2007;73(04):376-80.

20. Ooi KL, Muhammad TST, Tan ML, Sulaiman SF. Cytotoxic, apoptotic and anti-a-glucosidase activities of 3, 4-di-O-caffeoyl quinic acid, an antioxidant isolated from the polyphenolic-rich extract of Elephantopus mollis Kunth. J Ethnopharmacol. 2011;135(3):685-95.

21. Li H, Li M, Wang G, Shao F, Chen W, Xia C, et al. EM23, a natural sesquiterpene lactone from elephantopus mollis, induces apoptosis in human myeloid leukemia cells through thioredoxin-and reactive oxygen speciesmediated signaling pathways. Front Pharmacol. 2016;7:77.

22. Yang J, Li Z-D, Hou C-Y, Li Z-Y, Li Q, Miao S-Y, et al. EM-2 inhibited autophagy and promoted $\mathrm{G} 2 / \mathrm{M}$ phase arrest and apoptosis by activating the JNK pathway in hepatocellular carcinoma cells. Acta Pharmacol Sin. 2020;42(7):1139-49.

23. Amatori S, Persico G, Fanelli M. Real-time quantitative PCR array to study drug-induced changes of gene expression in tumor cell lines. J Cancer Metastasis and Treatment. 2017:3:91.

24. Gasparotto EPL, Tognon R, Ferreira AF, Oliveira GLV, Palma PVB, Zanichelli $\mathrm{MA}$, et al. Deregulated expression of $\mathrm{A} 1, \mathrm{BCl}-2, \mathrm{BCl}-\mathrm{xL}$, and $\mathrm{MCl}-1$ antiapoptotic proteins and bid, bad, and Bax proapoptotic genes in polycythemia vera patients. Braz J Pharm Sci. 2011;47(4):873-86.

25. Lund P, Kotova I, Kedinger V, Khanwalkar H, Voltz E, Hahn WC, et al. Transformation-dependent silencing of tumor-selective apoptosis-inducing TRAIL by DNA hypermethylation is antagonized by decitabine. Mol Cancer Ther. 2011:10(9):1611-23.

26. Xiang T, Li L, Yin X, Yuan C, Tan C, Su X, et al. The ubiquitin peptidase UCHL1 induces G0/G1 cell cycle arrest and apoptosis through stabilizing p53 and is frequently silenced in breast cancer. PLoS One. 2012;7(1):e29783.

27. Robles Al, Bemmels NA, Foraker AB, Harris CC. APAF-1 is a transcriptional target of p53 in DNA damage-induced apoptosis. Cancer Res. 2001;61(18):6660-4

28. Itharat A, Houghton PJ, Eno-Amooquaye E, Burke P, Sampson JH, Raman A. In vitro cytotoxic activity of Thai medicinal plants used traditionally to treat cancer. J Ethnopharmacol. 2004;90(1):33-8.

29. Artun FT, Karagoz A, Ozcan G, Melikoglu G, Anil S, Kultur S, et al. In vitro anticancer and cytotoxic activities of some plant extracts on HeLa and Vero cell lines. J BUON. 2016;21(3):720-5.

30. Coleman ML, Sahai EA, Yeo M, Bosch M, Dewar A, Olson MF. Membrane blebbing during apoptosis results from caspase-mediated activation of ROCK I. Nat Cell Biol. 2001;3(4):339-45. 
31. Eom Y-W, Kim MA, Park SS, Goo MJ, Kwon HJ, Sohn S, et al. Two distinct modes of cell death induced by doxorubicin: apoptosis and cell death through mitotic catastrophe accompanied by senescence-like phenotype. Oncogene. 2005;24(30):4765-77.

32. Robertson JD, Orrenius S, Zhivotovsky B. Nuclear events in apoptosis. J Struct Biol. 2000;129(2-3):346-58.

33. Porter $A G$, Jänicke RU. Emerging roles of caspase-3 in apoptosis. Cell Death Differ. 1999;6(2):99-104.

34. Wong RS. Apoptosis in cancer: from pathogenesis to treatment. J Exp Clin Cancer Res. 2011;30(1):1-14.

35. Graupner V, Alexander E, Overkamp T, Rothfuss O, De Laurenzi V, Gillissen $B F$, et al. Differential regulation of the proapoptotic multidomain protein Bak by p53 and p73 at the promoter level. Cell Death Differ. 2011;18(7):1130-9.

36. Thornborrow EC, Patel S, Mastropietro AE, Schwartzfarb EM, Manfredi JJ. A conserved intronic response element mediates direct p53-dependent transcriptional activation of both the human and murine bax genes. Oncogene. 2002;21(7):990-9.

37. López-Lázaro M. Two preclinical tests to evaluate anticancer activity and to help validate drug candidates for clinical trials. Oncoscience. 2015;2(2):91.

38. Ku B, Liang $\mathrm{C}$, Jung JU, Oh B-H. Evidence that inhibition of BAX activation by $\mathrm{BCL}-2$ involves its tight and preferential interaction with the $\mathrm{BH} 3$ domain of BAX. Cell Res. 2011;21(4):627-41.
39. Dai H, Ding H, Meng XW, Lee S-H, Schneider PA, Kaufmann SH. Contribution of $\mathrm{BCl}-2$ phosphorylation to Bak binding and drug resistance. Cancer Res. 2013;73(23):6998-7008.

40. Krajewska M, Fenoglio-Preiser CM, Krajewski S, Song K, Macdonald JS, Stemmerman $\mathrm{G}$, et al. Immunohistochemical analysis of Bcl-2 family proteins in adenocarcinomas of the stomach. Am J Pathol. 1996;149(5):1449.

41. Kubo T, Kawano Y, Himuro N, Sugita S, Sato Y, Ishikawa K, et al. BAK is a predictive and prognostic biomarker for the therapeutic effect of docetaxel treatment in patients with advanced gastric cancer. Gastric Cancer. 2016;19(3):827-38.

42. Stommel JM, Wahl GM. Accelerated MDM2 auto-degradation induced by DNA-damage kinases is required for p53 activation. EMBO J. 2004;23(7):1547-56

43. Geng M, Wang L, Li P. Correlation between chemosensitivity to anticancer drugs and $\mathrm{BCl}-2$ expression in gastric cancer. Int J Clin Exp Pathol. 2013;6(11):2554.

\section{Publisher's Note}

Springer Nature remains neutral with regard to jurisdictional claims in published maps and institutional affiliations.
Ready to submit your research? Choose BMC and benefit from:

- fast, convenient online submission

- thorough peer review by experienced researchers in your field

- rapid publication on acceptance

- support for research data, including large and complex data types

- gold Open Access which fosters wider collaboration and increased citations

- maximum visibility for your research: over $100 \mathrm{M}$ website views per year

At BMC, research is always in progress.

Learn more biomedcentral.com/submissions 